Hal. $91-108$

\title{
PENGARUH KECERDASAN INTELEKTUAL DAN SPIRITUAL TERHADAP KINERJA MELALUI MOTIVASI DAN KEPUASAN KERJA PEGAWAI KPP PRATAMA JEMBER
}

\author{
Fani Alifah Robbil \\ Jurusan Manajemen Fakultas Ekonomi dan Bisnis Universitas Jember \\ fani.robbil2@gmail.com
}

\begin{abstract}
The purpose of this study were to determine the effect of intellectual and spiritual intelligence on the performance through motivation and job satisfaction at Kantor Pelayanan Pajak Pratama Jember. This study included explanatory research with quantitative method. The population in this study were all employees of the KPP Pratama Jember number 102 employeesThe variables of this research were the intellectual, spiritual intelligence, motivation, job satisfaction and performance. The results showed that the Intelligence intellectual had significant effect employee motivation KPP Pratama Jember. Intelligence spiritual had significant effect employee motivation KPP Pratama Jember. Intellectual had no significant effect on employee job satisfaction of employees KPP Pratama Jember. Intelligence spiritual had significant effect on employee satisfaction KPP Pratama Jember. Intellectual acumen has no significant effect on employee performance KPP Pratama Jember. Intelligence spiritual had significant effect employee performance KPP Jember. Motivation effect on employee satisfaction KPP Pratama Jember. Employee satisfaction had significant effect employee performance KPP Pratama Jember.
\end{abstract}

Keywords: Intellectua Lintelligence, Spiritual Intelligence, and Performance.

\begin{abstract}
Abtrak: Tujuan penelitian ini adalah untuk mengetahui pengaruh kecerdasan intelektuil dan spiritual terhadap kinerja melalui motivasi dan kepuasan kerja pegawai Kantor Pelayanan Pratama Jember. Penelitian ini termasuk dalam penelitian penjelasan (explanatory research) dengan metode kuantitatif. Populasi dalam penelitian ini adalah seluruh karyawan KPP Pratama Jember sejumlah 102 pegawai. Variabel penelitian ini adalah kecerdasan intelektual, kecerdasan spiritual, kinerja serta motivasi dan kepuasan kerja sebagai variabel moderasi. Hasil penelitian menunjukkan bahwa Kecerdasan intelektual berpengaruh signifikan terhadap motivasi pegawai pegawai KPP Pratama Jember. Kecerdasan spiritual berpengaruh signifikan terhadap motivasi pegawai KPP Pratama Jember. Kecerdasan intelektual tidak berpengaruh signifikan terhadap kepuasan kerja pegawai pegawai KPP Pratama Jember. Kecerdasan spiritual berpengaruh signifikan terhadap kepuasan kerja pegawai KPP Pratama Jember. Kecerdasan intelektual tidak berpengaruh signifikan terhadap kinerja pegawai KPP Pratama Jember. Kecerdasan spiritual berpengaruh signifikan terhadap kinerja pegawai KPP Pratama Jember. Motivasi pegawai berpengaruh signifikan terhadap kepuasan kerja pegawai KPP Pratama Jember. Kepuasan kerja pegawai berpengaruh signifikan terhadap kinerja pegawai KPP Pratama Jember.
\end{abstract}

Kata kunci: Kecerdasan Intelektual, Kecerdasan Spiritual, dan Kinerja

\section{Pendahuluan}

Pembaharuan sistem administrasi perpajakan akan memberikan pengaruh kepada peningkatan kualitas peranan adminis $\neg$ trasi perpajakan dalam penyelenggaraan tugas-tugas pemerintahan dan pembangunan, khususnya dalam penyelenggaraan pembiayaan negara. Untuk mencapai tujuan tersebut, Direktorat Jenderal Pajak harus selalu melakukan perbaikanperbaikan pelayanan kepada masyarakat pada umumnya dan Wajib Pajak pada khususnya. Sebagai salah satu lembaga yang terkait dengan pelayanan 
publik, penerapan New Management Publik (NPM) sangat penting dilakukan untuk merubah manajemen sektor publik dari sistem manajemen tradisional yang kaku, birokratis, dan hirarkis menjadi model manajemen sektor publik yang fleksibel dan lebih mengakomodasi pasar. Sehingga diharapkan akan mampu memperbaiki efisiensi dan efektifitas sektor publik, meningkat $\neg$ kan daya respon lembaga publik terhadap klien dan pelang $\neg$ gannya, mengurangi pengeluaran publik dan memperbaiki akuntabilitas manajerial (Mahmudi, 2003: 36).

Menurut Kaho (1997: 60), faktor yang paling penting yang mempengaruhi pelaksanaan pelayanan publik adalah manusia yang bertindak sebagai pelaksana pembangunan harus baik karena manusia merupakan pelaku utama dalam setiap kegiatan pemerintahan. Oleh karena itu, penilaian kinerja pegawai sangat penting dilakukan sebagai upaya meningkatkan kualitas SDM dan meningkatkan pelayanan terhadap masyarakat dalam bentuk kinerja pegawai. Kinerja karyawan dipengaruhi oleh sejumlah faktor antara lain motivasi, kepuasan kerja, kecerdasan, kemampuan, pengetahuan, keahlian, pendidikan, pengalaman, pelatihan, minat, sikap kepribadian kondisi-kondisi fisik dan kebutuhan fisiologis, kebutuhan sosial dan kebutuhan egoistik (Sutermeister, 1999).

Motivasi dan kepuasan kerja merupakan faktor yang dapat mempengaruhi kinerja pegawai (Sulima et al, 2000:76). Penelitian Antonioni (dalam Habibah, 2001:27), menyebutkan bahwa salah satu cara untuk meningkatkan kinerja individu adalah dengan mekanisme umpan balik yang dikenal dengan konsep 360 derajat. Kinerja pegawai juga dapat ditingkatkan dengan menciptakan motivasi dan kepuasan kerja sehingga dengan demikian kinerjanya dapat lebih meningkat (Widiantoro, 2001:56).Kepuasan kerja mencerminkan perasaan seseorang terhadap pekerjaannya ini nampak dalam sikap positif pegawai terhadap pekerjaan dan segala sesuatu yang dihadapi di lingkungan kerjanya. Pernyataan tersebut menyiratkan makna bahwa dengan sikap positif pegawai terhadap pekerjaannya akan dapat mendorong motivasi kerja pegawai, yang pada akhirnya akan tercapai kinerja pegawai yang baik. Hal itu menunjukkan bahwa kepuasan kerja akan berpengaruh terhadap kinerja pegawai. Ostroff (1992) dan Suharto (2005) yang membuktikan adanya pengaruh antara kepuasan kerja dengan kinerja pegawai yang hasilnya 
menunjukkan bahwa terdapat hubungan positif dan signifikan antara kepuasan kerja terhadap kinerja pegawai. Bond dan Bunce (2007) kepuasan berpengaruh terhadap kinerja karyawan 800 orang customer service di AS. Jones et al. (2008) menunjukkan bahwa ada hubungan positif antara kepuasan kerja karyawan dengan kinerja karyawan. Nerkar, et al. (1996) menemukan

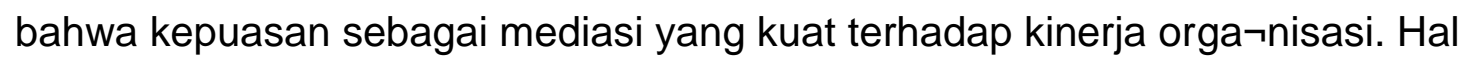
ini berarti bahwa agar kinerja positif dan mendu $k$ kung pencapaian organisasi maka perusahaan harus memperhatikan dan memberikan pemenuhan terhadap faktor-faktor yang mempengaruhi kepuasan kerja. Sedangkan Redmond (2016) menemukan bahwa kepuasan kerja tidak berpengaruh terhadap kinerja.

Motivasi iniberkaitandengan kinerja karyawan. Oleh Karena itu, pada dasarnya motivasi seseorang dipengaruhi oleh beberapa faktor yang berasal dari dalam dirinya (internal) maupun motivasi di luar dirinya (eksternal). Motivasijuga perludiketahui oleh setiap pimpinan, setiap orang yang bekerjadenganbantuanorang lain. Motivasi merupakan proses untuk mencoba mempengaruhi seseorang agar melakukan sesuatu yang diinginkan (Heidjrachman dan Husnan, 2000). Berdasarkan hasil penelitian McClelland et al. dalam (Hedberg et al.; 2002) menyimpulkan bahwa ada hubungan yang positif antara motivasi dan pencapaian prestasi. Artinya manajer yang mempunyai motivasi tinggi cenderung memiliki prestasi kerja yang tinggi, dan sebaliknya jika mereka yang prestasi kerjanya rendah dimungkinkan karena motivasi yang rendah (Anwar, 2004). Zameer et al. (2014:293) menunjukkan bahwa motivasi berpengaruh terhadap kinerja karyawan di industri minuman dari Pakistan. Sedangkan Dhermawan (2012) menunjukkan bahwa motivasi tidak berpengaruh terhadap kinerja.

Adanya motivasi dan kepuasan kerja dalam mempengaruhi kinerja juga diperhatikan pada instansi pajak yang terbentuk adalah KPP Pratama Jember yang merupakan jenis KPP yang terakhir yaitu jenis KPP selain KPP Besar dan KPP Madya. Lokasi KPP ini lebih tersebar di seluruh wilayah Indonesia. Kantor ini merupakan KPP modern yang menangani WP terbanyak dan merupakan ujung tombak bagi Ditjen Pajak untuk menambah rasio perpajakan di Indonesia. 
Kantor Pelayanan Pajak (KPP) Pratama Jember merupakan suatu instansi pemerintah yang bernaung dibawah Kementerian Keuangan Republik Indonesia bagian Direktorat Jenderal Pajak yang mempunyai tugas melaksanakan penyuluhan,pelayanan,dan pengawasan Wajib Pajak dibidang Pajak Penghasilan, Pajak Pertambahan Nilai, Pajak Penjualan atas Barang Mewah, dan Pajak Tidak Langsung. Kantor Pelayanan Pajak (KPP) Pratama Jember melakukan tugas tersebut bertujuan untuk menghimpun penerimaan pajak baik dari masyarakat maupun perusahaan.

Adanya ketidakpuasan yang terjadi akan berakibat pada kinerja pegawai yang ada. Kinerja pegawai tidak hanya dilihat dari kemampuan kerja yang sempurna, tetapi juga kemampuan menguasai dan mengelola diri sendiri serta kemampuan dalam membina hubungan dengan orang lain (Martin, 2000:22).. Kemampuan tersebut oleh Goleman (2000:46) disebut dengan Emotional Intelligence atau kecerdasan emosi. Goleman (2000:46) melalui penelitiannya mengatakan bahwa kecerdasan emosi menyumbang $80 \%$ dari faktor penentu kesuksesan seseorang, sedangkan $20 \%$ yang lain ditentukan oleh IQ (Intelligence Quotient).

Orang mulai sadar pada saat ini bahwa tidak hanya keunggulan intelektual saja yang diperlukan untuk mencapai keberhasilan tetapi diperlukan sejenis keterampilan lain untuk menjadi yang terdepan. Boyatzis (2001:2) menemukan bahwa orang yang tepat dalam organisasi bukanlah hal yang mudah, karena yang dibutuhkan oleh suatu perusahaan bukan hanya orang yang berpendidikan lebih baik ataupun orang yang berbakat saja. Ada faktorfaktor psikologis yang mendasari hubungan antara seseorang dengan organisasinya. Faktor- faktor psikologis yang berpengaruh pada kemampuan seseorang di dalam organisasi diantaranya adalah kemampuan mengelola diri sendiri, inisiatif, optimisme, kemampuan mengkoordinasi emosi dalam diri, serta melakukan pemikiran yang tenang tanpa terbawa emosi.

Sejak lama orang yakin bahwa kecerdasan khususnya kemampuan intelektualnya merupakan suatu apparatus dari wujud kemampuan mental yang penting dalam melaksanakan tugas atau pekerjaan. Hal ini dapat dipahami karena dalam bekerja bukan hanya tindakan-tindakan untuk melaksanakan pekerjaan tetapi juga kecerdasan dalam memecahkan masalah (Schultz and Schultz, 1994:82). Riggio (2000:43) memiliki pendapat yang lain. Penelitian 
yang pernah dilakukannya menyebutkan bahwa kecerdasan saja tidak terlalu memadai, karena kecerdasan hanya suatu alat. Hal tersebut bertentangan dengan penelitian Suhariadi (2002:348). Hasil penelitian yang didapat adalah intelligensi berpengaruh dalam membentuk produktivitas yang efisien pada diri seseorang (Suhariadi, 2000:348). Sedangkan Shipley (2013) menemukan bahwa kecerdasan tidak berpengaruh signifikan terhadap kinerja.

Salah satu bentuk kecerdasan lain adalah kecerdasan spiritual yangmemungkinkan seseorang untuk berpikir kreatif, berwawasan jauh, membuat atau bahkan mengubah aturan, yang membuat orang tersebut dapat bekerja lebih baik. Zohar dan Marshal (2001:23) mengatakan bahwa kecerdasan spiritual mampu menjadikan manusia sebagai mahluk yang lengkap secara intelektual, emosional dan spiritual. Hal tersebut seperti juga yang ditulis oleh Mudali (2002:3) bahwa menjadi pintar tidak hanya dinyatakan dengan memiliki IQ yang tinggi, tetapi untuk menjadi sungguh-sungguh pintar seseorang haruslah memiliki kecerdasan spiritual (SQ).

Tujuan penelitian ini adalah: (a) Untuk mengetahui pengaruh kecerdasan intelektuil terhadap motivasi pegawai Kantor Pelayanan Pratama Jember; (b) Untuk mengetahui pengaruh kecerdasan spiritualterhadap motivasi pegawai Kantor Pelayanan Pratama Jember; (c) Untuk mengetahui pengaruh kecerdasan intelektuil terhadap kepuasan pegawai Kantor Pelayanan Pratama Jember; (d) Untuk mengetahui pengaruh kecerdasan spiritualterhadap kepuasan pegawai Kantor Pelayanan Pratama Jember.

\section{Metodologi}

Penelitian ini bermaksud untuk menjelaskan pengaruh antar variabel melalui pengujian hipotesis dan sekaligus melakukan eksplanasi terhadap beberapa variabel, maka rancangan penelitian ini adalah penelitian eksplanatori (explanatory research). Waktu pengumpulan data dilakukan pada bulan Mei 2016. Lokasi penelitian adalah Kantor Pelayanan Pajak (KPP) Pratama Jember.

Populasi dalam penelitian ini adalah seluruh pegawai Kantor Pelayanan Pratama Jember yang berjumlah 102 pegawai. Penelitian ini merupakan penelitian populasi, penelitian ini menggunakan metode sensus dimana yang 
menjadi sampel penelitian adalah seluruh pegawai Kantor Pelayanan Pratama Jember yang berjumlah 102 pegawai.

Variabel bebas merupakan variabel konkrit yang pengaruhnya dapat dilihat atau diteliti dimana dalam penelitian ini adalah kecerdasan intelektual (X1) dan kecerdasan spiritual (X2). Variabel antara aalam penelitian ini adalah motivasi (Z1) dan kepuasan kerja (Z2). Variabel tergantung antara lain dalam penelitian ini adalah kinerja pegawai $(Y)$

\section{Hasil dan Pembahasan}

\section{Hasil Analisis Structural Equation Modelling (SEM)}

Berdasarkan cara penentuan nilai dalam model, maka variabel pengujian model pertama ini dikelompokkan menjadi variabel eksogen (exogenous variabel) dan variabel endogen (endogenous variable). Variabel eksogen adalah variabel yang nilainya ditentukan di luar model. Variabel endogen adalah variabel yang nilainya ditentukan melalui persamaan atau dari model hubungan yang dibentuk, termasuk dalam kelompok variabel eksogen adalah kecerdasan intelektual (X1), Kecerdasan Spiritual (X2) dan variabel endogenmotivasi (Z1), kepuasan kerja (Z2) dan kinerja pegawai (Y).

Model dikatakan baik bilamana pengembangan model hipotesis secara teoritis didukung oleh data empirik. Hasil uji konstruksi model awal berdasarkan goodness of fit index, kriteria model serta nilai kritisnya yang memiliki kesesuaian data. Berdasarkan haisl pengujian maka dapat diketahui bahwa model layak digunakan dengan mengamsumsikan prinsip Parsemonymemenuhi kriteria karena sudah ada lebih dari satu memenuhi sehingga model ini layak digunakan. Evaluasi model menunjukkan dari delapan kriteria goodness of fit index sudah semua yang memenuhi kriteria dan sudah mendekati nilai kritis yang disarankan, dengan demikian merujuk pada prinsip parsimony, model secara keseluruhan dapat dikatakan telah sesuai dengan data dan dapat di analisis lebih lanjut.

Setelah diketahui bahwa model dalam analisis ini telah fit maka analisis selanjutnya adalah mengetahui tingkat hubungan dan signifikansi atau kebermaknaan hubungan antar variabel yang ada dalam penelitian ini. Hasil pengujian dengan program AMOS memberikan hasil model persamaan struktural yang menunjukkan adanya hubungan antar variabel kecerdasan 
intelektual dengan motivasi, kecerdasan dengan motivasi, kecerdasan intelektual dengan kepuasan kerja, kecerdasan dengan kepuasan kerja, motivasi dengan kepuasan, kecerdasan intelektual dengan kinerja, kecerdasan dengan kinerja, motivasi dengan kepuasan kerja, dankepuasan dengan kinerja.

Hipotesis pertama dan kedua dalam penelitian ini menyatakan bahwa kecerdasan intelektual dan kecerdasan spiritual berpengaruh signifikan dan positif terhadap motivasi pegawai. Nilai koefisien jalur antara kecerdasan intelektual terhadap motivasi adalah sebesar 0,380 dengan nilai C.R 2,201 lebih dari nilai kritis yang disyaratkan sebesar 2. Sedangkan untuk variabel Kecerdasan spiritual terhadap Motivasi memiliki nilai koefisien jalur sebesar 0,894 dengan nilai C.R sebesar 5,466 lebih dari nilai kritis sebesar 2 sebagaimana yang disyaratkan. Hasil ini mendukung (menerima) hipotesis pertama dan kedua pada penelitian ini yang menyatakan kecerdasan intelektual dan kecerdasan spiritual berpengaruh signifikan dan positif terhadap motivasipegawai KPP Pratama Jember.

Hipotesis ketiga dan keempat dalam penelitian ini menyatakan bahwa kecerdasan intelektual dan kecerdasan spiritual berpengaruh signifikan terhadap kepuasan kerjapegawai KPP Pratama Jember. Berdasarkan hasil analisis yang ada ternyata nilai koefisien jalur kecerdasan intelektual terhadap kepuasan kerja pegawai adalah sebesar 0,414 dengan niai C.R 1,475 . Nilai C.R ini lebih besar dari nilai kritis yang disyaratkan sebesar 2. Sehingga dengan demikian dapat dinyatakan bahwa kecerdasan intelektual berpengaruh signifikan dan positif terhadap kepuasan kerjapegawai KPP Pratama Jember. Sedangkan untuk kecerdasan memiliki nilai koefisien jalur dengan kepuasan kerja pegawai sebesar 0,684 dengan nilai C.R sebesar 2,206. Nilai C.R ini lebih kecil dari nilai C.R yang disyaratkan yakni sebesar 2. Berdasarkan hasil tersebut maka dapat disimpulkan bahwa kecerdasan intelektualtidak berpengaruh signifikan terhadap kepuasan kerja pegawai. Hasil ini menolak hipotesis ketiga dan menerimahipotesis keempat pada penelitian ini yang menyatakan kecerdasan intelektualtidak berpengaruh signifikan terhadap kepuasan kerjapegawai KPP Pratama Jember sedangkan kecerdasan spiritual berpengaruh signifikan terhadap kepuasan kerjapegawai KPP Pratama Jember. 
Hipotesis kelima dan keenam dalam penelitian ini menyatakan bahwa kecerdasan intelektual dan kecerdasan spiritual berpengaruh signifikan terhadap kinerja pegawai KPP Pratama Jember. Berdasarkan hasil analisis yang ada ternyata nilai koefisien jalur kecerdasan intelektual terhadap kinerja pegawai adalah sebesar -0,134 dengan niai C.R 0,614. Nilai C.R ini lebih kecil dari nilai kritis yang disyaratkan sebesar 2. Sehingga dengan demikian dapat dinyatakan bahwa kecerdasan intelektualtidak berpengaruh signifikan dan positif terhadap kinerja pegawai KPP Pratama Jember. Sedangkan untuk kecerdasanemosional memiliki nilai koefisien jalur dengan kinerja pegawai sebesar 0,045 dengan nilai C.R sebesar 2,702. Nilai C.R ini lebih besar dari nilai C.R yang disyaratkan yakni sebesar 2 . Berdasarkan hasil tersebut maka dapat disimpulkan bahwa kecerdasan spiritual berpengaruh signifikan terhadap kinerja pegawai. Hasil ini menolak hipotesis kelima dan menerimakeenam pada penelitian ini yang menyatakan kecerdasan spiritual berpengaruh signifikan terhadap kinerja pegawai KPP Pratama Jember.

Hipotesis ketujuh dalam penelitian ini menyatakan bahwa motivasi berpengaruh signifikan terhadap kepuasan kerja pegawai KPP Pratama Jember. Berdasarkan hasil analisis yang ada ternyata nilai koefisien jalur motivasi terhadap kepuasan kerja pegawai adalah sebesar 0,045 dengan nilai C.R 2,075. Nilai C.R ini lebih kecil dari nilai kritis yang disyaratkan sebesar 2. Maka dapat disimpulkan bahwa motivasi berpengaruh signifikan terhadap kepuasan ketujuhkeenam pada penelitian ini yang menyatakan bahwa motivasi berpengaruh signifikan dan positif terhadap kepuasan kerjapegawai KPP Pratama Jember.

Hipotesis kedelapan dalam penelitian ini menyatakan bahwa motivasi berpengaruh signifikan terhadap kinerja pegawai KPP Pratama Jember. Berdasarkan hasil analisis yang ada ternyata nilai koefisien jalur motivasi terhadap kinerja pegawai adalah sebesar 0,045 dengan nilai C.R 2,075. Nilai C.R ini lebih kecil dari nilai kritis yang disyaratkan sebesar 2. Maka dapat disimpulkan bahwa motivasi berpengaruh signifikan terhadap kepuasan ketujuhkeenam pada penelitian ini yang menyatakan bahwa motivasi berpengaruh signifikan dan positif terhadap kinerjapegawai KPP Pratama Jember. 
Hipotesis kesembilan dalam penelitian ini menyatakan bahwa kepuasan kerja berpengaruh signifikan terhadap kinerja pegawai KPP Pratama Jember. Berdasarkan hasil analisis yang ada ternyata nilai koefisien jalur kepuasan kerja terhadap kinerja pegawai adalah sebesar 0,263 dengan nilai C.R 2,463. Nilai C.R ini lebih besar dari nilai kritis yang disyaratkan sebesar 2. Maka dapat disimpulkan bahwa kepuasan kerja berpengaruh signifikan terhadap kinerja pegawai KPP Pratama Jember. Hasil ini mendukung (menerima) hipotesis kedelapan pada penelitian ini yang menyatakan bahwa kepuasan kerja berpengaruh signifikan dan positif terhadap kinerja pegawai KPP Pratama Jember. Berdasarkan hasil yang ada maka dapat disimpulkan bahwa semua hipotesis terbukti sedangkan hipotesis empat, lima dalam penelitian tidak terbukti berpengaruh.

\section{Pembahasan}

Faktor motivasi, kepuasan kerja dan kinerja pegawai merupakan sesuatu yang penting di dalam suatu organisasi, karena banyak penelitian menunjukkan bahwa motivasi dan kepuasan kerja pegawai berhubungan dengan peningkatan kinerja pegawai. Berdasarkan analisis data sebelumnya dapat diketahui beberapa faktor sumber daya manusia antara lain kecerdasan intelektual dan kecerdasan spiritual berpengaruh terhadap motivasi, kepuasan kerja pegawai dan kinerja pegawai pada KPP Pratama Jember. Hasil tersebut didukung pula dengan hasil jawaban responden terhadap faktor-faktor Sumber Daya Manusia, motivasi dan kepuasan kerja pegawai dan kinerja pegawai KPP Pratama Jember. Hasil studi tersebut dijelaskan pada sub bab sebagai berikut:

Pengaruh Kecerdasan Intelektual terhadap Motivasi Pegawai

Ada keterkaitan antara kecerdasan intelektual terhadap motivasi pegawai. Kecerdasan intelektual merupakan ciri khas yang menunjukkan perbedaan seseorang tentang kecerdasan intelektual, inisiatif, kemampuan untuk tetap tegar menghadapi tugas sampai tuntas atau memecahkan masalah atau bagaimana menyesuaikan diri dengan lingkungan yang akan mempengaruhi pola perilaku individu. Seseorang sangat dipengaruhi oleh kecerdasan intelektualnya baik ketika sebagai manajer ataupun sebagai bawahan yang konstribusinya dalam pengambilan keputusan dan bertindak yang sangat berkaitan dengan kinerja organisasi 
Persepsi pegawai terhadap faktor kecerdasan intelektual secara keseluruhan menunjukkan bahwa sebagian responden mempunyai persepsi sangat setuju tentang faktor kecerdasan intelektual. Berarti pegawai KPP Pratama Jember mempunyai kecerdasan intelektual yang diukur melalui kemampuan, sikap dan minat yang berpengaruh pada kepuasan seseorang. Dengan adanya kecerdasan intelektual akan menyebabkan adanya dorongan yang menimbulkan motivasipegawai untuk melakukan pekerjaan dengan baik.

Berdasarkan nilai perhitungan jalur terlihat ada pengaruh secara langsung yang diberikan faktor kecerdasan intelektual terhadap motivasipegawaiKPP Pratama Jember. Berarti semakin tinggi persepsi terhadap kecerdasan intelektualpegawai maka akan semakin tinggi dorongan pegawaiuntuk melakukan pekerjaan lebih baik. Demikian juga sebaliknya, semakin rendah kecerdasan intelektualpegawai maka motivai pegawai akan semakin rendah pula. Kemampuan, sikap dan minat pegawai akan menunjang motivai pegawai dalam segala aktivitas pekerjaan.

Hal ini konsisten dengan Goleman (2007:44) dimana kecerdasan intelektual hanya menyumbang 20 persen dalam peningkatan kinerja, sedangkan 80 persen dipengaruhi oleh bentuk-bentuk kecerdasan lain seperti kecerdasan emosional. Seseorang yang memiliki kecerdasan emosional mampu untuk mengatur perasaannya dengan baik, memotivasi diri sendiri, berempati ketika menghadapi gejolak emosi diri maupun dari orang lain. Rahmasari (2016) menemukan bahwa kecerdasan intelektual berpengaruh terhadap motivasi karyawan.

\section{Pengaruh Kecerdasan Spiritual Terhadap Motivasi Pegawai}

Kecerdasan merupakan kemampuan untuk mengenali emosi diri maka individu mampu untuk menyadari perasaan serta mampu memonitor perasaan tersebut agar selaras dengan situasi yang terjadi. Bila individu bisa mengelola emosinya maka ia akan dengan mudah menjaga keseimbangan emosinya dan bukan menekan emosi. Dengan mengelola emosi individu cenderung memiliki energi yang positif berupa gairah, semangat, ketekunan, serta memiliki motivasi untuk selalu memberikan yang terbaik bagi perusahaannya.

Berdasarkan nilai perhitungan analisis jalur terdapat pengaruh yang ditimbulkan variabel kecerdasan spiritual terhadap motivasi pegawai secara 
langsung. Berarti semakin baik kecerdasan maka akan semakin tinggi motivasi kerja pegawai. Sebaliknya semakin rendah kecerdasan yang diterapkan maka akan semakin rendah motivasi pegawai. Kecerdasan spiritual akan membuat pegawai memiliki kemudahan untuk melaksanakan segala pekerjaan sehingga terdorong mengerjakan dengan baik. Hasil ini didukung dengan penilaian responden terhadap indikator kecerdasan spiritual yang menunjukkan bahwa sebagian besar responden memiliki persepsi yang baik tentang kecerdasan.

Hasil penelitian ini mendukung pendapat Golleman (2001:42) danpenelitian Maideri (2008) yang menyatakan bahwa kecerdasan spiritual berpengaruh positif dan signifikan terhadap motivasi pegawai. Implikasi hasil penelitian ini menunjukkan bahwa semakin baik kecerdasan spiritual maka akan semakin tinggi motivasi pegawai.

\section{Pengaruh Kecerdasan intelektual terhadap Kepuasan Kerja Pegawai}

Kecerdasan intelektual dari seorang pegawai yang meliputi kemampuan akan mampu meningkatkan kepuasan kerja pegawai itu sendiri. Persepsi pegawai terhadap faktor kecerdasan intelektual secara keseluruhan menunjukkan bahwa sebagian responden mempunyai persepsi sangat setuju tentang faktor kecerdasan intelektual dan kepuasan kerja. Berarti pegawai KPP Pratama Jember mempunyai kecerdasan intelektual yang diukur melalui kemampuan, sikap dan minat menimbulkan kepuasan kerja pegawai dalam bekerja.

Berdasarkan nilai perhitungan jalur terlihat tidak ada pengaruh secara langsung yang diberikan faktor kecerdasan intelektual terhadap kepuasan kerja pegawai KPP Pratama Jember. Hal itu berarti semakin tinggi persepsi terhadap kecerdasan intelektualpegawai atas suatu pekerjaan belum tentu kepuasna kerja tercapai. Demikian juga sebaliknya, semakin rendah kecerdasan intelektualpegawai maka rasa puas terhadap hasil tidak mudah dirasakan karena adanya beban dalam melaksanakan tugas dan pekerjaannya. Kemampuan, sikap dan minat pegawai akan menunjang bagaimana pegawai tersebut dapat menikmati hasil kerja yang dilakukan dengan segala ciri khas yang dipunyai. Setiap pegawai memiliki kemampuan baik fisik dan kognitif serta sikap dan minat yang berbeda-beda dalam melakukan pekerjaannya sehingga hasil yang diterimanya akan menimbulkan kepuasan yang berbeda -beda pula. 
Menurut Subyantoro (2009), setiap orang mempunyai pandangan, tujuan, kebutuhan dan kemampuan yang berbeda satu sama lain. Perbedaan ini akan terbawa dalam dunia kerja,yang akan menyebabkan kepuasan satu orang denganyang lain berbeda pula, meskipun bekerja di tempat yang sama. Pegawai yang mempunyai kecerdasan intelektual yang tinggi maka akan lebih mudah mendapatkan kepuasan kerja yang diinginkan. Karena dengan adanya kecerdasan intelektual tersebut akan terpacu untuk melaksanakan segala pekerjaan tanpa dibebani dengan perasaan yang berat.

Hasil ini berbeda dengan teori Robbin dan Judge (2008:57) dimana kecerdasan intelektual dapat diukur dengan kemampuan yang terdiri dari kemampuan intelektual dan fisik, kecerdasan, usia, jenis kelamin, ras dan pengalaman. Penelitian ini juga tidak sesuai dengan penelitian Serebriakoff dan Langer (1999:141) dalam Laely (2010:7) menjelaskan kecerdasan intelektual berhubungan dengan keterampilan penggunaan anggota badan yang terkoordinasi, minat seseorang, seperti: mempunyai ingkup minat yang luas, pengamatan yang tajam, mampu mengingat dengan cepat, berimaginasi, mempunyai berbagai hobi, dan keterampilan mekanis

\section{Pengaruh Kecerdasan Spiritual terhadap Kepuasan Kerja Pegawai}

Kecerdasan emosi diperlukan dalam mengelola emosi individu cenderung memiliki energi yang positif berupa gairah, semangat, ketekunan, serta memiliki motivasi untuk selalu memberikan yang terbaik bagi perusahaannya.Berdasarkan nilai perhitungan analisis jalur tidak terdapat pengaruh yang ditimbulkan variabel Kecerdasan spiritual terhadap motivasipegawai secara langsung. Berarti semakin baik kecerdasanmeningkatkan kepuasan kerja pegawai. Hal itu dikarenakan kepuasan kerja banyak faktor yang memengaruhinya terutama faktor dari intansi sendiri misalnya gaji, tunjangan, penghargaan dan lain-lain. Hal ini berarti kecerdasan emosi hanya diperlukan sebagai upaya dan kemampuan untuk mengendalikan emosi dalam pekerjaan tetapi tidak semata-mata karena kecerdasan spiritual tetapi bisa dipengaruhi oleh faktor lain.

Hasil penelitian ini mendukung pendapat Golleman (2001:42) danpenelitian Maideri (2008) yang menyatakan bahwa kecerdasan spiritual berpengaruh positif dan signifikan terhadap motivasi pegawai. Implikasi hasil 
penelitian ini menunjukkan bahwa semakin baik kecerdasan pimpinan dan staf maka akan semakin tinggi motivasi pegawai. Selain itu, penelitian ini konsisten dengan Vendy (2010:131) kecerdasan spiritual adalah kecerdasan yang merefleksikan antara unsur jasmani dan rohani. Zohar dan Marshall (2002) dalam Tikolah dkk (2006: 6) menemukan bahwa kecerdasan spiritual berpengaruh terhadap kepuasan kerja

Pengaruh Faktor Kecerdasan Intelektual dan Kecerdasan spiritual terhadap Kinerja Pegawai

Berdasarkan data perhitungan analisis jalur dan pengujian hipotesis tampak bahwa faktor kecerdasan intelektualtidka berpengaruh positif yang signifikan terhadap kinerja pegawai. Keadaan tersebut terjadi karena adanya penilaian kerja yang merupakan kumpulan total dari kerja yang merupakan tugas dan ciri individu guna mencapai sasaran/target yang ditentukan pimpinan. Secara keseluruhan faktor kecerdasan intelektual dan kecerdasan spiritual berpengaruh terhadap kinerja pegawai. Meskipun didukung dengan jawaban responden secara keseluruhan menunjukkan bahwa sebagian responden mempunyai persepsi sangat baik tentang kinerja pegawai. Berarti pegawai KPP Pratama Jember selalu berupaya dalam meningkatkan kinerja pegawai. Pengaruh masing-masing faktor dijelaskan sebagai berikut.

1. Pengaruh Faktor Kecerdasan intelektual terhadap Kinerja Pegawai

Seseorang sangat dipengaruhi oleh kecerdasan intelektualnya baik ketika sebagai manajer ataupun sebagai bawahan yang konstribusinya dalam pengambilan keputusan dan bertindak yang sangat berkaitan dengan kinerja organisasi (Leonard et al., 2004). Kecerdasan intelektual yang meliputi kemampuan, sikap dan minat akan berpengaruh terhadap hasil yang dicapai oleh seorang pegawai sehingga dapat mempengaruhi kinerja pegawai pada sebuah instansi atau organisasi.

Berdasarkan nilai perhitungan analisis jalur menunjukkan bahwa kecerdasan intelektualtidak berpengaruh signifikan terhadap kinerja pegawai KPP Pratama Jember. Berarti semakin tinggi kecerdasan intelektual pegawai atas suatu pekerjaan belum tentu meningkatkan kinerja. Demikian juga sebaliknya, semakin rendah kecerdasan intelektual pegawai kinerja yang diinginkan. Kecerdasan intelektual yang menunjukkan kemampuan pegawai dalam melaksanakan pekerjaan, sikap 
pegawai dan minat dalam menyelesaikan tugas yang diberikan akan mempengaruhi pola kerja dan hasil kerja pegawai itu sendiri. Pegawai yang mempunyai kemampuan yang tinggi baik fisik dan kognitif, sikap yang baik dan minat yang besar dalam melakukan pekerjaan maka akan lebih mudah menyelesaikan pekerjaan sehingga meningkatkan kinerja pegawai. Karena dengan adanya kecerdasan intelektual merupakan salah satu faktor yang mendukung untuk bekerja lebih giat sehingga hasilnya optimal. Dengan hasil yang optimal maka kinerja yang diharapkan akan lebih meningkat.

Hasil penelitian ini berbeda dengan teori yang dikemukakan Robbins (2003) bahwa kecerdasan intelektual yang meliputi kemampuan dalam pekerjaan, sikap dan minat pegawai akan memberikan dukungan seseorang untuk bekerja menjadi lebih baik sehingga kinerjanya meningkat. Hal ini juga tidak mendukung penelitian yang dilakukan penelitian Trihandini (2005:72) berdasarkan hasil penelitiannya menunjukkan bahwa semakin baik kecerdasan sepiritual yang dimiliki karyawan maka akan semakin baik kinerja yang ditunjukkan oleh karyawan..

2. Pengaruh Faktor Kecerdasan Spiritual Terhadap Kinerja pegawai

Berdasarkan nilai perhitungan analisis jalur pengaruh langsung yang ditimbulkan Kecerdasan spiritual terhadap kinerjapegawai. Kecerdasan spiritual berpengaruh positif terhadap kinerja pegawai pada KPP Pratama Jember. Berarti kecerdasanpegawai atas suatu pekerjaan semakin tinggi maka akan meningkatkan kinerja. Karena dengan adanya kecerdasan tersebut akan memberikan contoh dan kepuasan untuk bekerja lebih giat sehingga hasilnya optimal. dengan hasil yang optimal maka kinerja pegawai yang diharapkan akan lebih meningkat.

Hasil penelitian ini terlihat ada pengaruh faktor Kecerdasan spiritual terhadap kinerjapegawaiKPP Pratama Jember melalui kepuasanpegawai. Hal itu menunjukkan persepsi terhadap kecerdasan yang setuju akan menyebabkan pegawai menimbulkan kepuasan sehingga pegawai akan melakukan pekerjaan secara optimal. Apabila hasil kerja optimal maka dapat meningkatkan kinerja pegawai 
3. Pengaruh Faktor Kepuasan Kerja terhadap Kinerja Pegawai

Kepuasan kerja merupakan perasaan gembira atau positif yang dimiliki oleh pegawai terhadap pekerjaan itu sendiri, ganjaran yang diterima ataupun perasaan yang berhubungan dengan dirinya. Karena itu maka kepuasan kerja menyangkut perasaan yang bukan berarti tidak perlu diperhatikan sebab kepuasan kerja akan tercermin pada hasil pekerjaan. Oleh karena itu, pimpinan sebagai manajer dituntut lebih profesional agar mampu menimbulkan kepuasan kerja pada pegawai.

Berdasarkan pengujian dengan analisis jalur tampak bahwa kepuasan kerja pegawai berpengaruh positif terhadap kinerja pegawai terbukti signifikan. Semakin tinggi kepuasan kerja yang dicapai oleh pegawai maka akan meningkatkan kinerja pegawai. Hal itu disebabkan adanya kesan positif yang timbul pada pegawai akan menyebabkan adanya dorongan intrisik untuk mencapai hasil kerja yang diharapkan akan optimal. Adanya hasil penelitian ini juga didukung dengan jawaban responden secara keseluruhan yang menunjukkan bahwa sebagian responden mempunyai persepsi sangat setuju tentang kinerja. Hal itu menunjukkan bahwa pegawai KPP Pratama Jember mempunyai usaha dalam meningkatkan kinerja.

Pengaruh yang ditimbulkan oleh kepuasan terhadap kinerja pegawai tersebut adanya kepuasan kerja yang dicapai pegawai akan berpengaruh secara langsung terhadap kinerja pegawai KPP Pratama Jember. Hasil penelitian ini konsisten dengan penelitian Menurut Mathis (2001:23), kepuasan kerja merupakan hasrat di dalam seseorang yangmenyebabkan orangtersebutmelakukan tindakan untukmencapai tujuan. Menurut Robbins (2008:54), kepuasan kerja adalah proses yang menjelaskan intensitas, arah dan ketekunan usaha untuk mencapai suatu tujuan. Sumber kepuasan kerja seseorang berbeda-beda, karena tidak ada manusia yang sama satu sama lain. Akan tetapi yang terpenting bahwa dengan kepuasan kerja yang dimilikinya itu, orang tersebut akan lebih mempunyai ketahanan dan kekuatan untuk mencapai apa yang diinginkannya. Bagi seorang karyawan yang bekerja di dalam organisasi, kepuasan kerjanya untuk mencapai tujuan organisasi akan membuatnya bersemangat untuk melaksanakan pekerjaannya. Jika karyawan 
bersemangat dalam bekerja, maka kinerjanya akan meningkat. Selain itu, komitmen karyawan akan terbentuk untuk mencapai kinerja yang telah ditetapkan. Berdasarkan uraian tersebut, kepuasan kerja yang dimiliki karyawan mempunyai pengaruh yang positif terhadap kinerja karyawan (Sunarcaya, 2008:32). Hasil ini sesuai dengan Rahardja (2004) yang menyatakan bahwa kepuasan kerja yang diberikan kepada karyawan akan meningkatkan hasil kerja (kinerja) yang telah dilakukan oleh karyawan.

\section{Kesimpulan}

Berdasarkan hasil studi yang dilakukan pada KPP Pratama Jember maka dapat disimpulkan hal-hal sebagai berikut: (1) Kecerdasan intelektual berpengaruh terhadap motivasi pegawai pegawai KPP Pratama Jember. Hasil studi ini menunjukkan bahwa kecerdasan intelektual berpengaruh signifikan terhadap motivasi pegawai. Semakin tinggi kecerdasan intelektual maka akan meningkatkan motivasi pegawai KPP Pratama Jember; (2) Kecerdasan spiritual berpengaruh terhadap motivasi pegawai KPP Pratama Jember. Hasil studi ini menunjukkan bahwa kecerdasan spiritual berpengaruh signifikan terhadap motivasi pegawai. Semakin tinggi kecerdasan spiritual maka akan meningkatkan motivasi pegawai KPP Pratama Jember; (3) Kecerdasan intelektual tidak berpengaruh signifikan terhadap kepuasan kerja pegawai pegawai KPP Pratama Jember. Hasil studi ini menunjukkan bahwa kecerdasan intelektual tidak berpengaruh signifikan terhadap kepuasan kerja pegawai; (4) Kecerdasan spiritual berpengaruh terhadap kepuasan kerja pegawai KPP Pratama Jember. Hasil studi ini menunjukkan bahwa kecerdasan spiritual berpengaruh signifikan terhadap kepuasan kerja pegawai. Semakin tinggi kecerdasan spiritual maka akan meningkatkan kepuasan kerja pegawai KPP Pratama Jember; (5) Kecerdasan intelektual tidak berpengaruh signifikan terhadap kinerja pegawai KPP Pratama Jember. Hasil studi ini menunjukkan bahwa kecerdasan intelektua Iberpengaruh signifikan terhadap kinerja pegawai, berarti semakin tinggi kecerdasan intelektual belum tentu kinerja pegawai KPP Pratama Jember meningkat; (6) Kecerdasan spiritual berpengaruh terhadap kinerja pegawai KPP Pratama Jember. Hasil studi ini menunjukkan bahwa kecerdasan spiritual berpengaruh signifikan terhadap kinerja pegawai. Semakin tinggi kecerdasan spiritual maka akan meningkatkan 
kinerja pegawai KPP Pratama Jember; (7) Motivasi pegawai berpengaruh terhadap kepuasan kerja pegawai KPP Pratama Jember. Hal itu disebabkan adanya peningkatan motivasi pegawai menyebabkan adanya peningkatan kepuasan kerja pegawai; dan (8) Kepuasan kerja pegawai berpengaruh terhadap kinerja pegawai KPP Pratama Jember. Hal itu disebabkan adanya peningkatan kepuasan kerja pegawai menyebabkan adanya keterlibatan pegawai untuk mencapai hasil kerja yang diharapkan akan optimal. Apabila hasil kerja optimal sesuai dengan dinas maka kinerja pegawai juga akan meningkat sesuai dengan prestasi yang diperoleh.

\section{Saran}

Berdasarkan hasil pembahasan dan kesimpulan studi ini, maka disarankan hal-hal sebagai berikut: (1) Pengaruh motivasi sangat rendah terhadap kepuasan kerja pegawai pimpinan di KPP Pratama Jember. Oleh karena itu, pihak KPP Pratama harus senantiasa mengadakan motivasi untuk meningkatkan motivasi dengan melakukan pengawasan yang continue terhadap pegawai; dan (2) Pihak manajemen diharapkan dapat mengadakandiklat dan workshop yang berkaitan dengan sosialisasi penerapan motivasi di antara pegawai.

\section{Daftar Referensi}

Anwar Ali Shah G. Syed dkk, 2012, Motivation as a Tool for Effective Staff Productivity in the Public Sector: A Case Study of Raw Materials Research and Development Council of Nigeria, Asian Social Science, Vol. 8, No. 11

Arikunto. Suharsimi. 2006. Prosedur Penelitian Suatu Pendekatan Praktek. Jakarta : PT. Rineka Cipta

Bond, F. W. dan Bunce, D. 2007. The Role of Acceptance and Job Control in Mental Health, Job Sastisfaction, and Work Performance. Journal of Applied Psychology, $88,1057-10102$

Clifford, P. McCue. ad Gerasmus, A, Glanakis. 1997. The Relationship Between JobSatisfaction and Performance The Case of Local Government Finance of in Ohio Public Productivity and Management Review. Vo.21. No.2. p.170-191

Ellickson, Mark C. and Kay, Logsdon. 2001. Determinants of Job Satisfaction of Municipal Government Employees. State and Local Government Review Vol. 33. No. 3: $173-84$ 
Fendy Suhariadi. 2002. Pengaruh Inteligensi dan Motivasi Terhadap Semangat Penyempumaan Dalam Membentuk Perilaku Produktif Efisien. Anima: Indonesia Psikologi Jurnal. Vol. 17. No. 4. Juli 2002. p. 346

Gazioglu, Saziye dan Tansel, Aysıt.2002. Job Satisfaction in Britain: Individual and Job Related Factors. ERC Working Papers in Economics 03/03 January

Goleman, Daniel . 2000. Emotional Intellegence. Alih bahasa: T. Hermaya. Jakarta: Gramedia Pustaka

Gomes Cardoso. Faustino. 2001. Manajemen Sumber Daya Manusia. Yogyakarta: Andi Offset

Kaho. 1997. Reformasi dan Profesionalisme Sumber Daya Manusia. Jurnal Manajemen Daya Saing. Volume 1. Nomor 1 hal. 42-47. Jakarta.

Mahmudi, 2003. Manajemen Kinerja Sektor Publik Jakarta: Unit Penerbit dan Percetakan akuntansi Manajemen Perusahaan YKPN.

Patton, P. 1998.Kecerdasan Emosional di Tempat Kerja. Alih Bahasa: Zaini Dahlan. Pustaka Delaprata. Jakarta

Rahman, Arrafur dan makmur. 2016. Perilaku Spiritualdan KepuasanKerja KaryawanPerusahaanPabrik Kelapa Sawit. JurnalllmiahCanoEkonomosVol.4No.1Januari

Rahmasari , Lisda. 2016. Pengaruh Kecerdasan Intelektual, Kecerdasan Emosi dan Kecerdasan Spiritual Terhadap Kinerja Karyawan. Jurnal Ekonomi Bisnis. Uki.Vol.5 No.2

Schultz, D.P. and Schultz. S.E. 1994. Psychology and Work Today. An Introduction To Industrial and Organizational Psychology. Sixth Edition.Ma

Zameer, Hashim, 2014, The Impact of the Motivation on the Employee's Performance in Beverage Industry of Pakistan, International Journal of Academic Research in Accounting, Finance and Management Sciences, Vol.4, No.1, pp.293-298

Zohar, D. Marshal. I. 2000. SQ (Spiritual Intelligence) : The Ultimate Intelligence. Blomsburry Publishing. London 